Policy Research Working Paper 2623

Trade Liberalization in

China's Accession to the World Trade Organization

Elena Ianchovichina

Will Martin

The World Bank

Development Research Group

Trade

June 2001
China's forthcoming access to the World Trade Organization involves reform in many sectors, both domestic and trade-related. The starting point for reform is a partially reformed economy with relatively high import duties, in which export sectors benefit from liberal duty exemptions on inputs. Both China and its major trading partners will gain from access - with China gaining most Iperhaps half of the estimated $\$ 56$ billion in annual welfare gains). Some developing countries will suffer small losses because of increased competition from China. The adjustments required are greatly reduced by China's dramatic iberalization in the 1990 s. 
Policy Research Working Paper 2623

\section{Summary findings}

Before reform, China's trade was dominated by a few foreign trade corporations with monopolies on the trade of specific ranges of products. Planners could control imports through these corporations so there was little need for conventional instruments such as tariffs, quotas, and licenses. Trade reforms increased the range of enterprises eligible to trade in specific commodities and led to the development of indirect new trade instruments, such as duty exemptions. Duty exemptions almost completely liberalized the imports of intermediate inputs used to produce exports and investment gooas used in join ventures with foreign enterprises.

Comprehensive liberalization measures in China's World Trade Organization (WTO) accession package will help ease this problem as tariff reduction reduces the costs of domestic inputs to exporters. WTO commitments will also lead to the abolition of most nontariff barriers and of quotas on textiles and clothing.

With accession, China 's share of world exports may almost double between 1995 and 2005-an estimate that is smaller than those found in studies that do not incorporate duty exemptions. (Duty exemptions were a fo" $\mathrm{m}$ of partial liberalization, so any further reduction in p. otection will boost trade volume less than some estimate.) With reform, labor-intensive industries are expected to grow most, especially exports of apparel. Wages of unskilled workers should rise.

This paper-a product of Trade, Development Research Group-is part of a larger effort in the group to assess the implications of trade reform for developing countries. Copies of the paper are available free from the World Bank, 1818 H Street, NW, Washington, DC 20433. Please contact Lili Tabada, room MC3-333, telephone 202-473-6896, fax 202522-1159, email address ltabada@worldbank.org. Policy Research Working Papers are also posted on the Web at http://econ.worldbank.org. The authors may be contacted at eianchovichina@worldbank.org or wmartin1@worldbank.org. June 2001. (35 pages)

The Policy Research Working Paper Series disseminates the findings of work in progress to encourage the exchange of ideas about development issues. An objective of the series is to get the findings out quickly, even if the presentations are less than fully polished. The papers carry the names of the authors and should be cited accordingly. The findings, interpretations, and conclusions expressed in this paper are entirely those of the authors. They do not necessarily represent the view of the World Bank, its Executive Directors, or the countries they represent. 


\title{
Trade Liberalization in China's Accession to the World Trade Organization
}

\author{
by \\ Elena Janchovichina and Will Martin \\ World Bank
}

JEL Classification: F02, F13, F14. Corresponding Author: Will Martin, MSN3-303, World Bank, 1818 H St NW, Washington DC 20433. Ph 1-202-473-3853. Fax 1-202-522-1159. Email: wmartin1@worldbank.org 



\section{Non-technical summary}

China's forthcoming accession to the WTO involves reforms across a wide range of sectors in China, both in directly trade-related sectors and behind the border. The implications of these reforms are greatly influenced by the starting point-a partially reformed economy with relatively high import duties, but in which export sectors benefit from liberal duty exemptions on their inputs. This paper traces the evolution of China's trade regime and forms an initial assessment of some of the likely implications of the trade reforms involved in China's accession to the WTO.

The pre-reform Chinese trade regime was dominated by a small number of Foreign Trade Corporations (FTC) with monopoly trading rights. Since import and export volumes could be controlled by planners through the monopoly trading corporations, there was little need for conventional policy instruments such as tariffs, quotas, or licenses. An important aspect of trade reform in China was an increase in the number and types of enterprises eligible to trade. Another important feature was an increase in the importance of indirect trade policy instruments that were absent or unimportant under the planning system. These reforms were inextricably bound up with reforms at the enterprise level, and in the pricing system.

Given the high rates of protection in the early reform phase, special arrangements for processing trade were needed if China was to utilize its comparative advantage in labor-intensive manufactures. Duty exemptions almost completely liberalized imports of intermediate inputs used for the production of exports and imports of investment goods needed by foreign-invested firms. Export processing industries developed, frequently with a heavy reliance on imported intermediates and with little domestic value added.

The comprehensive liberalization measures in China's accession package will phase out nontariff barriers and sharply reduce tariffs. This will reduce the importance of special processing arrangements by lowering the costs of domestic inputs to exporters. Most importantly, the quotas on textiles and clothing that tightly restrict China's exports of textiles and clothing will be phased out.

We estimate that with accession China's share of world exports will almost double between 1995 and 2005 . While this is a large increase, it is much smaller than would have been found if duty exemptions had not been considered. This is because duty exemptions are a form of partial liberalization that is incorporated in China's current trade patterns. Labor-intensive industries are estimated to grow the most with the reforms, and China's share of world apparel exports is projected to grow dramatically under the dual influence of reduced costs and abolition of the export quotas. The expansion of labor-intensive industries is expected to have a favorable impact on wages of unskilled workers. China is expected to be the largest beneficiary of the market liberalization, receiving around half of the estimated $\$ 56$ billion in annual welfare gains. The major industrial countries gain from the elimination of the quotas they currently impose on China, and its major trading partners gain from increases in the supply of China's exports and in its demand for imports. In some developing countries, these gains are outweighed by increased competition from China in third markets. 



\section{Trade Liberalization in China's Accession to WTO}

\section{INTRODUCTION}

Accession to the WTO will be a major milestone in China's economic development, modernization and integration into the world economy. Completion of the accession formalities will not be the end, but rather the beginning, of a new process of reform and adaptation that builds on the sweeping economic changes begun in 1978 .

The reform era in China, and other East Asian transition economies (Martin, 2001), has been a period of extraordinary growth in trade and output. Part of the growth in trade has been a consequence of economic reforms that have stimulated opening to the outside world, and part has been a consequence of the economic growth that opening to the world has done so much to facilitate. Recognition of the benefits of openness for growth and poverty reduction has been an important element in China's willingness to make the difficult reforms that will be involved in WTO accession.

Like the process of economic reform in China more generally, the process of trade policy reform has been complex and incremental-a process of crossing the river by feeling the stones. A consequence of this has been that the reforms required by accession will begin from quite a set of policies that contains many features inherited from earlier eras - such as state trading monopolies that date to the command economy, and of duty exemptions and rebates that date from the need in the early reform era to stimulate laborintensive exports of manufactures despite a regime of high trade barriers.

China's likely accession agreement is likewise complex. It reflects the intersection of the interests and concerns of policy makers in China and those in WTO members involved in the accession negotiations. While the agreement will involve 
widespread reductions in protection, it cannot be represented as a move to free trade or a simple proportional cut in protection as many studies have tried to do (see Gilbert and Wahl (2001) for a survey). While WTO accession and the process of liberalization that preceded it represent one of the most profound liberalizations in recent economic history, China will still be far from fully open after the reforms. In many areas, significant policy interventions remain, and their effects need to be taken into account in any evaluation of the WTO accession package, or in consideration of future policy reforms. Looking forward, an area of particular interest will be the role of policies inherited from earlier trade regimes, such as state trading in agriculture, and the system of duty exemptions for exports.

In this paper, we form an initial assessment of some of the likely major implications of the trade reforms involved in China's accession to the WTO. We build on recent work by Fan and Li (2000), USITC (1999), Wang (2001), Fan and Zheng (2000), and the Development Research Centre (1998). Our objectives are two-fold-to assess the implications of the reforms; and to identify areas in which further analysis will be helpful in guiding further reform.

Because of the importance of understanding China's current regime and its origins, we begin with a discussion of policy reforms and China's current trade regime. We then examine the nature of the reforms associated with accession. Then, we outline the modeling approach that we have used to analyze this liberalization. It takes into account the special features of the initial trade regime and the trade reforms, associated with accession. Finally, we discuss some results from the analysis. 


\section{CHINA'S TRADE POLICIES}

China's trade regime still retains a number of features that date from the prereform era, and it is important to be aware of the evolution of the system if contemporary trade policies, and some of the points of resistance to reform, are to be understood. We begin with a short description of the pre-reform system, and trace the evolution of the current system through the reform era.

The Pre-Reform Chinese Trade Regime

The pre-reform Chinese trade regime was dominated by between 10 and 16 Foreign Trade Corporations (FTCs) with effective monopolies in the import and export of their specified product ranges (Lardy, 1991). Planned import volumes were determined by the projected difference between domestic demand and supply for particular goods, with export volumes set at levels necessary to finance planned imports.

An interesting feature of the pre-reform Chinese trade regime was the limited importance of conventional trade policy instruments such as tariffs, quotas and licenses. Price-based measures such as tariffs were obviously unimportant since the planning system was based on quantity decisions rather than behavioral responses to prices. There was little need for quotas or licenses since the quantities to be imported could be controlled through the monopoly trading corporations.

\section{Reform of China's Trade Regime}

Reform of China's trade regime had four major dimensions: increasing the number and type of enterprises eligible to trade beyond the initial handful of centrally controlled foreign trade corporations; developing the indirect trade policy instruments, such as tariffs, licenses, quotas, and duty exemption schemes, that were absent or 
unimportant under the planning system; reducing and ultimately removing the exchange rate distortion; and reforming prices so that they could play a role in guiding resource allocation. These reforms of the trading system were inextricably linked with reform of the enterprise sector to allow indirect regulation through market-determined prices to replace direct regulation of enterprise outputs.

The number of FTCs with trading rights was progressively expanded, with trading rights provided to branches of the FTCs controlled by the central government, and to those controlled by regions and localities, until there were thousands of these firms. Since 1984, these trading enterprises have been legally independent economic entities (Kueh, 1987) and state owned trading enterprises of this type now appear to operate very strongly along commercial lines (Rozelle et al, 1996). Joint ventures between domestic and foreign firms, and firms located in the special economic zones were also allowed to trade their own products relatively early during the reform process. At a later stage, large producing firms began to gain direct foreign trade rights.

Despite the large number of trading firms overall, there are two broad groups of commodities for which the number of firms entitled to engage in trade is tightly restricted. One of these groups is subject to state trading, while the other is subject to designated trading ${ }^{1}$. The commodity groups covered by these restrictions are given in Table 1.

\footnotetext{
${ }^{1}$ Under designated trading, trading rights are restricted to a relatively small number of firms, many of which have geographically restricted trading rights.
} 
Table 1. Products covered by state trading and designated trading.*

\begin{tabular}{l|l|l}
\hline & \multicolumn{1}{|c|}{ Imports } & \multicolumn{1}{c}{ Exports } \\
\hline State trading & $\begin{array}{l}\text { Grain, vegetable oils, sugar, } \\
\text { tobacco, crude oil, refined oil, } \\
\text { chemical fertilizer, cotton }\end{array}$ & $\begin{array}{l}\text { Tea, maize, soybeans, tungsten, } \\
\text { coal, crude oil, refined oil, silk, } \\
\text { unbleached silk, cotton and } \\
\text { products, antimony }\end{array}$ \\
\hline Designated trading & $\begin{array}{l}\text { Rubber, timber, plywood, wool, } \\
\text { acrylics, steel and products }\end{array}$ & $\begin{array}{l}\text { Rubber, timber, plywood, wool, } \\
\text { acrylics, steel and products }\end{array}$ \\
\hline
\end{tabular}

*Source: Government of China, 2000.

The system of coordination and control used for major state-traded commodities such as grains and fertilizer follows the basic lines used under the traditional planning system. Recent empirical research concludes that, rather than helping to stabilize domestic grain prices, this inflexible system contributes substantially to the volatility of domestic grain prices (World Bank, 1997a). Carter, Chen and Rozelle (1998) identified many of the classic features of the traditional monopoly trading system in the grain trade--an "airlock" between buyers and suppliers; poor quality matching; and unpredictable timing of deliveries. In addition, they found many of the features of poorly operating markets, particularly concerns that traders are using their superior information to take advantage of buyers in China. While state trading is clearly GATT-legal, there appears to be a strong case on economic grounds for reforming these arrangements.

An important feature of the reforms was the introduction of special arrangements for processing trade, such as duty exemptions and rebates of Value Added Tax payments. Imports of intermediate inputs for use in the production of exports were almost completely liberalized, as were capital goods inputs for use in joint ventures with foreign enterprises. These categories of imports came to represent a very large share of total 
imports, with intermediate inputs into exports accounting for almost $44 \%$ of total imports in $1999 .^{2}$

The primary transitional device used to reduce, and ultimately remove, the distortions in both commodity prices and exchange rates was the two (or more) tier pricing system. Under the two-tier pricing system for commodities, the plan price continued to operate for the quantity of the commodity that producers were contracted to supply. However, to stimulate output, producers were allowed to supply additional output at a secondary market price. The two tier system for foreign exchange involved an overvalued official exchange rate and a higher secondary-market rate, and distorted trade by discouraging both exports and imports (Martin, 1993; World Bank, 1994). Over time, the gaps between official and secondary market prices were narrowed or eliminated, and the two-tier system for foreign exchange was abolished with unification of the exchange rate in 1994.

\section{Nontariff and Tariff Barriers to Trade}

Over the course of the 1990's China has made substantial progress in reducing the number of nontariff barriers in its trade regime. Nicholas Lardy (personal communication) estimates that the number of products subject to quotas and licenses fell from 1247 tariff lines in 1992 to 261 in 1999 . The average protective impact of the complete set of nontariff barriers in China was estimated to be 9.3 percent in the mid1990s (World Bank, 1997b). The protective effect of these nontariff barriers has clearly declined since this estimate was made, because of the progressive phase out of NTBs and a standstill on introduction of new NTBs during the accession process.

\footnotetext{
${ }^{2}$ Source: Customs General Administration, People's Republic of China.
} 
The pace of tariff reform in China has also been rapid. While average tariffs were very high in the early 1990 s, they fell sharply after 1994. A significant tariff reform in October 1997, reduced average tariffs significantly below 20 percent. Three subsequent tariff reductions, on January 1 of 1999, 2000 and 2001 have further reduced tariffs on a wide range of items. Some basic data on trends in average tariff rates are given in Table 2.

Table 2. Changes in average tariff rates in China (\%)

\begin{tabular}{lcccccc}
\hline & \multicolumn{2}{c}{ All products } & \multicolumn{2}{c}{ Primany products } & \multicolumn{2}{c}{ Manufactures } \\
& Simple & Weighted & Simple & Weighted & Simple & Weighred \\
\hline 1992 & $42.9^{*}$ & 40.6 & 36.2 & 22.3 & 44.9 & 46.5 \\
1993 & 39.9 & 38.4 & 33.3 & 20.9 & 41.8 & 44.0 \\
1994 & 36.3 & 35.5 & 32.1 & 19.6 & 37.6 & 40.6 \\
1996 & 23.6 & 22.6 & 25.4 & 20.0 & 23.1 & 23.2 \\
1997 & 17.6 & 18.2 & 17.9 & 20.0 & 17.5 & 17.8 \\
1998 & 17.5 & 18.7 & 17.9 & 20.0 & 17.4 & 18.5 \\
\hline
\end{tabular}

*Source: World Bank (1999, p340)

The progressive reductions in tariffs since 1992 have reduced average tariffs by more than half over the period, with larger than average cuts in the manufacturing sector. These reductions mean that the fall in tariffs to the levels proposed in the WTO negotiations will be much less abrupt than would otherwise have been the case. Another important feature of the reforms has been a substantial reduction in the dispersion of tariff rates-with the standard deviation of tariffs falling from 32.1 percent in 1992 to 13.1 percent in 1998.

An important feature of China's tariff reforms has been the inclusion of exemptions for processing trade and for foreign investment. According to China's Customs authorities, 60 percent of imports entered either duty-free or subject to reduced duties in 2000. The exempt and reduced categories, with their 1999 import shares in 
parentheses, were processing trade (41 percent, exempted), initial investment of joint ventures (13 percent, exempted), and other exempted/reduced (6 percent, exempted or reduced).

China's heavy reliance on exemptions for goods used in the production of exports has clearly stimulated the development of export processing industries that rely heavily on imported intermediates. Having this ability is good since global manufacturing is moving towards production sharing, with the production chain broken up into many links located wherever comparative advantage is greatest (Deardorff, 2001). However, the use of high protective barriers and deep exemptions has the disadvantage of discriminating against industries that rely more heavily on domestic inputs by raising the prices of locally produced goods ${ }^{3}$ and factors (through the real exchange rate effect).

More comprehensive liberalization should help reduce this problem. With lower tariffs, the costs of domestic inputs to exporters will fall. This, in turn, can be expected to result in a shift towards reliance on exports with stronger forward and backward linkages in the economy.

\footnotetext{
${ }^{3}$ In principle, China's system of tariff exemptions allows for indirect use, but these provisions do not always work effectively.
} 


\section{CHINA'S WTO ACCESSION PACKAGE}

The final details of China's WTO accession package will not be known until the agreement has been approved by WTO members. However, it seems likely that the November 1999 agreement between China and the United States, and the May 2000 agreement with the European Union, will form its basis and a substantial amount of information on these agreements is available. The US agreement appears to capture most of the reforms and was used in the analysis because its details are publicly available.

WTO entry will require China to bring its rules into line with WTO norms in a wide range of areas. Perhaps the most fundamental of these stipulations are those on nondiscrimination between suppliers in accordance with the Most Favored Nation principle; and the abolition of most nontariff barriers. However, WTO rules require much more, including implementation of Intellectual Property regimes consistent with the TRIPS agreement, and procedures in areas like customs valuation, safeguards, standards and phyto-sanitary restrictions that are consistent with WTO rules.

The Protocol of Accession will also include important stipulations designed to increase the transparency of China's trade regime and provide for judicial review of administrative decisions. It will specify procedures for judicial review of administrative actions, require the phasing out of the general restrictions on trading rights, require elimination of multi-tier pricing systems, and require state owned enterprises to make their purchasing and sales decisions based solely on commercial considerations. Unfortunately, the agreement is also likely to include transitional procedures that will make it easier for China's trading partners to impose product-specific protective barriers 
during the transition period, when China's trade mix is likely to need to adjust sharply in response to liberalization.

After WTO accession, China will move very strongly towards a trade regime based on tariffs. Quotas, licenses and designated trading are all to be phased out. State trading is allowed to remain on the commodities listed in Table 1, although it will become subject to WTO rules.

In addition, protection on merchandise and services will be reduced. China has committed to bind all agricultural and industrial tariffs (USTR, 1999). The simple average tariff on manufactures is to be reduced to 6.95 percent- $-\mathrm{a}$ substantial reduction from the 24.3 percent reported in Table 4 for 1995 . The simple average tariff for agriculture is reported to be 17 percent-broadly in line with the 1998 estimate in Table 4 for all primary products. In subsequent bilateral negotiations with the EU, China committed to tariff reductions on a number of additional products, including butter, olives, textiles, leather, spirits, and a range of machinery products.

The arrangements for textiles and clothing will be particularly important for China. Unlike most other developing country exporters, China was excluded from the Uruguay Round Agreement on Textiles and Clothing ${ }^{4}$. This means that China has not benefited from the integration of textile and clothing products into GATT or the increases in quota growth rates provided for under this agreement and the export tax equivalents of these measures have risen. Under the draft agreement (see www.uschina.org), China will benefit from the integration of textiles and clothing into GATT, and hence abolition of quotas, that has occurred since 1994 (WTO, 1994a). This process paves the way for

\footnotetext{
${ }^{4}$ This agreement applied only to members of the GATT 1947.
} 
expansion of China's exports of textiles and clothing, with all existing quotas to be phased out by 2005 , and any special textile safeguards introduced under the agreement phased out by 2008 . This aspect of the agreement is the only important case where China will benefit in terms of improved market access-all of the other benefits will arise from China's commitments to reduce its own barriers.

In agriculture, the main impacts of the WTO commitments are likely to operate through induced reductions in uncertainty about agricultural trade policies rather than through sharp reductions from current protection levels (Martin, 2001b). While state trading will be retained for some important commodities, the WTO's rules on state trading impose significant disciplines on the protection that state trading enterprises can provide (Davey, 1998). In particular, they require importing state trading enterprises to meet market demand, and limit their ability to restrict imports to the extent that the domestic price would consistently exceed the agreed tariff binding. China has committed not to use agricultural export subsidies, and its aggregate measure of support to agriculture will be subject to a limit of 10 percent or less.

The disciplines on agricultural protection may become extremely important if comparative advantage continues to shift against agriculture in China. In the absence of WTO disciplines, China would almost certainly have followed the general East Asian pattern of sharply rising agricultural protection (Anderson and Hayami, 1986). As is evident from Table 3, most of the agricultural bindings agreed by China are very low by East Asian standards (Hathaway and Ingco, 1996), and may turn out to save China from developing an extremely inefficient and high cost agricultural sector. Another important feature of Table 3 is the comparison of the bindings in the current proposal with those 
that China had offered in the Uruguay Round-illustrating how far China has been willing to come.

Table 3. Final tariff bindings on selected agricultural products* (\%)

\begin{tabular}{|c|c|c|}
\hline Commodity & Uruguay Round Final Binding & Likely Final Bindings \\
\hline Almonds & 30 & 10 \\
\hline Apples & 40 & 10 \\
\hline Barley & 91.2 & 9 \\
\hline Beef & 40 & 12 \\
\hline Citrus & 52 & 12 \\
\hline Grapes & 40 & 13 \\
\hline Pork, frozen cuts & 40 & 12 \\
\hline Poultry, frozen cuts & 40 & 12 \\
\hline Soybeans & 114 & 3 \\
\hline Wheat, Maize, Rice & 114 & 65 \\
\hline Wine & 135 & 14 \\
\hline
\end{tabular}

Rising agricultural protection is frequently justified as a measure to help small,

poor farmers. While increases in agricultural product prices may, indeed, have a beneficial impact in the short run (Ravallion and Chen, 2001), raising agricultural protection is not an effective policy for dealing with rural poverty. Most of the benefits go to larger producers, and there are inevitably substantial losses to net food buyers. Further, the long run returns to labor in agriculture are determined by the returns available outside the sector. Given the inevitable need to reduce employment in the sector as China grows, long-run solutions to rural poverty must involve policies that make it easier for workers to move out of the sector, and that raise their returns outside the sector.

The agricultural trade regime includes a range of Tariff Rate Quotas (TRQs) that provide for lower tariffs on specified quantities of imports. These commitments provide for some private participation in in-quota imports that will help make protection rates more readily observable. 
China has also made important commitments on services under GATS, including comprehensive commitments on distribution services and tourism; and wide-ranging commitments on telecommunications, insurance, banking, construction, professional and audiovisual services. The commitments on distribution are particularly important for merchandise trade because of the transparency they create, and because they preclude the emergence of de facto barriers through controls on distribution at any level of government. The coverage of these commitments exceeds the average for high-income countries in the Uruguay Round, and far exceeds that for most developing countries (Ianchovichina, Martin and Wood, 2000).

\section{Liberalization Resulting from Accession}

A comprehensive assessment of the implications of accession for trade barriers requires that we compare the protection prevailing after accession to what would have prevailed in the absence of accession. Given the rapid changes in China's protection rates since the early 1990 s, it is not clear what the counterfactual rate of protection should be. In general, we assume that the tariffs applying in the GTAP-4 database for 1995 would have continued to apply in the absence of accession ${ }^{5}$. We then estimate the protection applying after accession as the lesser of the applied and the bound rate.

In agriculture, we assume that protection rates will not decline from initial levels. There is considerable uncertainty about both the initial level of agricultural protection in China, and the effects of the WTO agreement on important commodities like wheat, corn and rice. Historically, the tariff equivalents of agricultural trade barriers in China have been variable, but appear to have been consistently negative in the 1980s (Findlay,

\footnotetext{
${ }^{5}$ In doing this, we are effectively treating the tariff reductions after 1995 as being undertaken as part of China's campaign to enter the WTO.
} 
Martin and Watson, 1993). In more recent years, the degree of taxation of China's agriculture has fallen, and some estimates of protection rates have become positive in some years. However, many studies still find negative protection rates in most periods (see, for example, Carter (2001)). Simple statistical analysis (Martin 2001b) suggests that the out-of-quota tariff on wheat (65 percent) is likely to be permitted in many years, potentially allowing protection on wheat to rise from current low levels. This seems unlikely for rice and maize, for which China is a net exporter.

For industrial products, we have detailed information on the tariff rates applying in 1995. These rates were aggregated up to the GTAP level using import data from the UN COMTRADE system. We used the trade-weighted average tariff rates as a conservative estimate of the initially-applied rate of protection. It seems clear that the protection created by NTBs has fallen substantially from the 9 percent estimated by World Bank (1997b), probably to a very low level on average. In the absence of better information, we preferred to adopt a known lower-bound estimate of protection, rather than to add highly speculative estimates of the rates of protection contributed by NTBs.

\section{Estimates of the Rates of Assistance to Various Sectors Before and After Accession}

Table 4 shows China's average tariff rates in the baseline (column 2) and in the case of WTO accession (column 3). ${ }^{6}$ As noted above, we assume no liberalization in agriculture, because the tariff bindings are estimated to be above the previously applied rates of protection. As Francois and Martin (1995) have emphasized, once the stochastic nature of protection is taken into account, even bindings above applied rates, such as

\footnotetext{
${ }^{6}$ The tariff rates are the statutory tariff rates, and not the de facto rates after adjusting for duty exemptions. The de facto rates after adjusting for duty exemption will be much smaller.
} 
these, may be important as a means to reduce both the mean and the variance of protection, and hence the cost of protection.

The numbers in this table highlight the substantial nature of the offer for industrial products. On average, tariffs on imported manufactures in China drop from 24.3 percent to about 7 percent. Protection of textiles and apparel products falls dramatically, as does protection to automobiles, electronics and petrochemicals. The sharp decline in protection to electronics is undoubtedly related to China's agreement to implement the Information Technology Agreement as part of its accession package. The actual reduction in protection to the automobile sector is even larger than is suggested by these tariff results, since quota protection to this sector is also to be phased out. Overall, China's offer lowers the weighted average tariff protection on imports to the country from 21.4 percent to 7.9 percent.

Table 4. Weighted average tariffs in China with and without WTO accession (\%)

\begin{tabular}{lcc}
\hline & Baseline & With Accession \\
\hline Foodgrains & 0.00 & 0.00 \\
Feedgrains & 6.03 & 6.03 \\
Oilseeds & 4.16 & 4.16 \\
Meat \& livestock & 10.14 & 10.14 \\
Dairy & 26.74 & 26.74 \\
Other agriculture & 22.09 & 22.09 \\
Other food & 27.68 & 27.68 \\
Beverages \& tobacco & 123.50 & 20.38 \\
Extractive industries & 3.59 & 1.26 \\
Textiles & 57.10 & 9.39 \\
Wearing apparel & 75.99 & 14.85 \\
Wood \& paper & 21.57 & 4.80 \\
Petrochemicals & 20.17 & 6.94 \\
Metals & 17.52 & 6.22 \\
Automobiles & 129.07 & 13.76 \\
Electronics & 21.69 & 3.44 \\
Other manufactures & 23.53 & 6.74 \\
Total - Agriculture & 17.09 & 16.88 \\
Total - Manufactures & 24.27 & 6.95 \\
Total & 21.41 & 7.85 \\
\hline
\end{tabular}




\section{ASSESSING CHINA'S ACCESSION TO THE WTO}

China's economy seems likely to continue growing at a relatively high rate in the early years of the new century, and this process of growth will cause substantial changes in the composition of output. In addition, the liberalization associated with WTO accession are likely to have important implications for the structure of output, the orientation of production between domestic and international markets, and the benefits from liberalization (Bach, Dimaranan, Hertel and Martin, 2000). To evaluate the impact of accession in this dynamic context, we assess the likely future growth in China's economy using a new version of the GTAP which models duty exemptions explicitly (Ianchovichina, Martin and Fukase, 2000).

We look at two scenarios - a baseline scenario in which China does not enter the WTO, and a companion scenario under which China enters the WTO. All experiments broadly replicate World Bank projections for overall output growth in each region, and use projections of factor input growth, and a residually determined level of total factor productivity growth to ensure broad consistency between the two. To avoid the increase in agricultural prices that would otherwise occur ${ }^{7}$, we specify a higher rate of productivity growth in agriculture (see Martin and Mitra (2001) for evidence) ${ }^{8}$ The protection rates used throughout were based on tariffs in (or near) the model's base year of 1995 .

\footnotetext{
${ }^{7}$ The evidence suggests that capital-labor and capital-output ratios have been rising world-wide (Nehru and Dhareshwar, 1993) and, under these circumstances, Rybczynski effects tend to pull resources out of the relatively labor-intensive agricultural sectors (Gehlhar, Hertel and Martin, 1994).

${ }^{8}$ The productivity growth rates in this study differ not only by region but also by sector. Based on the econometric work by Bernard and Jones (1996) for OECD agriculture over the $1970-87$ period, we assume that annual productivity growth in agriculture is $40 \%$ faster than that of manufacturing, in services it is half of the rate in manufacturing, in mining productivity growth is zero.
} 
Because the available projections suggest that the growth of factor endowments in high-growth regions such as East Asia will be highly unbalanced, the structure of output can be expected to change quite sharply as a result of Rybczynski effects. These pressures for change are in addition to those resulting from Engel effects in consumption, which are incorporated in the model through non-homothetic preferences in the consumer demand systems. The simulations have been performed over the period from the model's benchmark year of 1995 to 2005 . The results of these simulations provide an indication of the pressures for change resulting from the underlying dynamics of China's growth.

The details of the projection scenario are given in Table 5 as the changes prevailing over the period 1995-2005 (see Anderson et al (2000) for further discussion). These projections were generated by combining historical and forecast data from World Bank sources. The skilled labor projections, based on forecasts of the growth in the stock of tertiary educated labor in each developing country (Ahuja and Filmer, 1995) and projected growth rates of skilled labor in developed countries from the World Bank, provide an indication of changes in the stock of those qualified for employment as professional and technical workers. Projections of the stock of physical capital were calculated using a Harberger-type perpetual inventory method, that is, by adding investment net of depreciation to update the capital stock in each year. Data for initial physical capital stock for 1995 as well as annual forecasts of gross domestic investment were obtained from the World Bank.

As is evident from Table 5, the rate of workforce growth in China is projected to slightly outpace the growth of the population over the projection period, although not greatly because much of the demographic dividend (Bloom and Williamson, 1998) 
resulting from the sharp decline in the Chinese birthrate has now passed. Most important for the growth and structure of the economy are the very high projected growth rates for skilled labor and for physical capital. This augmentation of physical and human capital can be expected to have profound implications for growth and structural change.

Under the baseline scenario, tariff rates on all industrial products are held constant, and the MFA quotas are projected to grow at the rates determined in each country's agreements. Tariff rates on agricultural products are also held constant, in line with the move to tariffication in the Uruguay Round. Since the MFA quota growth rates for WTO members are subject to quota growth rate acceleration (WTO, 1994a), but those for nonmembers such as China are not, the MFA quota growth rates become an increasing burden for China in the absence of WTO accession.

The estimated implications of China's liberalization due to accession and its growth till 2005 are shown in Tables 6 through 10. These results provide the basis for a number of interesting conclusions. The first one is the rapid growth in China's shares of world output and exports even in the absence of WTO accession. ${ }^{9}$ Without accession, China's share of world output is projected to increase between 1995 and 2005 from 3.4 to 5.3 percent, and its share of exports from 3.7 to 4.8 percent. While the accession offer has almost no impact on the share of output, it has a significant impact on the share of trade. With the implementation of the accession offer, China's share of world export markets rises to 6.8 percent, and of world import markets, to 6.6 percent.

\footnotetext{
${ }^{9}$ China's demand for foodgrains and other agriçultural products grows rapidly without WTO accession, which is reflected in growing shares of both output and imports in the world market. This result is consistent with very strong income growth, averaging $7.4 \%$ every year for 10 years, and relatively high income elasticities with respect to agricultural commodities and food embedded in the GTAP parameter set (www.agecon.purdue.edu/gtap).
} 
Table 5. Percentage Growth Rates over the Period 1995-2005 (annual rates in parentheses)

\begin{tabular}{|c|c|c|c|c|c|}
\hline Regions & Population & $\begin{array}{l}\text { Unskilled } \\
\text { Labor }\end{array}$ & $\begin{array}{l}\text { Skilled } \\
\text { Labor }\end{array}$ & Capital & $\begin{array}{c}\text { Manufacturing } \\
\text { TFP* }\end{array}$ \\
\hline North America & $\begin{array}{c}11 \\
(1.05)\end{array}$ & $\begin{array}{c}14 \\
(1.29)\end{array}$ & $\begin{array}{c}39 \\
(3.33)\end{array}$ & $\begin{array}{c}63 \\
(4.98)\end{array}$ & low \\
\hline Western Europe & $\begin{array}{c}1 \\
(0.10)\end{array}$ & $\begin{array}{c}0 \\
(0.03)\end{array}$ & $\begin{array}{c}29 \\
(2.60)\end{array}$ & $\begin{array}{c}30 \\
(2.70)\end{array}$ & medium \\
\hline Australia/New Zealand & $\begin{array}{c}10 \\
(0.97)\end{array}$ & $\begin{array}{c}11 \\
(1.09)\end{array}$ & $\begin{array}{c}66 \\
(5.20)\end{array}$ & $\begin{array}{c}38 \\
(3.29)\end{array}$ & low \\
\hline Japan & $\begin{array}{c}2 \\
(0.20)\end{array}$ & $\begin{array}{c}-3 \\
(-0.29)\end{array}$ & $\begin{array}{c}32 \\
(2.83)\end{array}$ & $\begin{array}{c}29 \\
(2.59)\end{array}$ & low \\
\hline China & $\begin{array}{c}9 \\
(0.83)\end{array}$ & $\begin{array}{c}12 \\
(1.17)\end{array}$ & $\begin{array}{c}43 \\
(3.66)\end{array}$ & $\begin{array}{c}174 \\
(10.62)\end{array}$ & medium \\
\hline Taiwan, China & $\begin{array}{c}8 \\
(0.73)\end{array}$ & $\begin{array}{c}13 \\
(1.21)\end{array}$ & $\begin{array}{c}51 \\
(4.18)\end{array}$ & $\begin{array}{c}102 \\
(7.28)\end{array}$ & high \\
\hline Other NICs & $\begin{array}{c}9 \\
(0.84)\end{array}$ & $\begin{array}{c}8 \\
(0.73)\end{array}$ & $\begin{array}{c}66 \\
(5.18)\end{array}$ & $\begin{array}{c}71 \\
(5.54)\end{array}$ & low \\
\hline Indonesia & $\begin{array}{c}14 \\
(1.31)\end{array}$ & $\begin{array}{c}21 \\
(1.96)\end{array}$ & $\begin{array}{c}79 \\
(6.00)\end{array}$ & $\begin{array}{c}21 \\
(1.96)\end{array}$ & low \\
\hline Other Southeast Asia & $\begin{array}{c}19 \\
(1.73)\end{array}$ & $\begin{array}{c}26 \\
(2.36)\end{array}$ & $\begin{array}{c}79 \\
(6.00)\end{array}$ & $\begin{array}{c}38 \\
(3.30)\end{array}$ & low \\
\hline India & $\begin{array}{c}17 \\
(1.59)\end{array}$ & $\begin{array}{c}23 \\
(2.11)\end{array}$ & $\begin{array}{c}73 \\
(5.65)\end{array}$ & $\begin{array}{c}85 \\
(6.36)\end{array}$ & medium \\
\hline Other South Asia & $\begin{array}{c}23 \\
(2.10)\end{array}$ & $\begin{array}{c}33 \\
(2.92)\end{array}$ & $\begin{array}{c}77 \\
(5.87)\end{array}$ & $\begin{array}{c}56 \\
(4.52)\end{array}$ & medium \\
\hline Brazil & $\begin{array}{c}13 \\
(1.26)\end{array}$ & $\begin{array}{c}22 \\
(2.04)\end{array}$ & $\begin{array}{c}70 \\
(5.46)\end{array}$ & $\begin{array}{c}25 \\
(2.22)\end{array}$ & low \\
\hline Other Latin America & $\begin{array}{c}18 \\
(1.63)\end{array}$ & $\begin{array}{c}23 \\
(2.11)\end{array}$ & $\begin{array}{c}89 \\
(6.55)\end{array}$ & $\begin{array}{c}25 \\
(2.22)\end{array}$ & low \\
\hline Turkey & $\begin{array}{c}15 \\
(1.44)\end{array}$ & $\begin{array}{c}22 \\
(2.02)\end{array}$ & $\begin{array}{c}104 \\
(7.41)\end{array}$ & $\begin{array}{c}66 \\
(5.19)\end{array}$ & low \\
\hline Other Middle East \& North Africa & $\begin{array}{c}27 \\
(2.43)\end{array}$ & $\begin{array}{c}37 \\
(3.17)\end{array}$ & $\begin{array}{c}109 \\
(7.64)\end{array}$ & $\begin{array}{c}15 \\
(1.37)\end{array}$ & low \\
\hline Economies in Transition & $\begin{array}{c}3 \\
(0.27)\end{array}$ & $\begin{array}{c}6 \\
(0.60)\end{array}$ & $\begin{array}{c}69 \\
(5.37)\end{array}$ & $\begin{array}{c}30 \\
(2.70)\end{array}$ & low \\
\hline South African Customs Union & $\begin{array}{c}23 \\
(2.06)\end{array}$ & $\begin{array}{c}29 \\
(2.59)\end{array}$ & $\begin{array}{c}64 \\
(5.06)\end{array}$ & $\begin{array}{c}15 \\
(1.43)\end{array}$ & low \\
\hline Other Sub-Saharan Africa & $\begin{array}{c}33 \\
(2.87)\end{array}$ & $\begin{array}{c}37 \\
(3.19)\end{array}$ & $\begin{array}{c}88 \\
(6.50)\end{array}$ & $\begin{array}{c}19 \\
(1.78)\end{array}$ & medium \\
\hline Rest of World & $\begin{array}{c}18 \\
(1.65) \\
\end{array}$ & $\begin{array}{c}21 \\
(1.90) \\
\end{array}$ & $\begin{array}{c}83 \\
(6.22)\end{array}$ & $\begin{array}{c}88 \\
(6.51)\end{array}$ & low \\
\hline
\end{tabular}

*The low, medium, and high growth assumptions for total factor productivity (TFP) in manufacturing correspond to annual growth rates of $0.1 \%, 1.0 \%$, and $2.0 \%$, respectively. 
At the sectoral level, the most important impact of accession is on China's output of apparel. Production of apparel rises by 263 percent over the ten year period, compared to 57 percent in the baseline (columns 2 and 3, Table 7), and results in an increase in China's share of world output of apparel from 8.84 percent in the baseline to 20.10 percent in the case of accession (columns 3 and 4, Table 6). This share rises dramatically because of the lifting of the burdens imposed by the MFA on China's exports, and by China's protection on the cost structure of the industry. China's apparel 
Table 6. Output, Exports and Imports as a Share of the World Economy

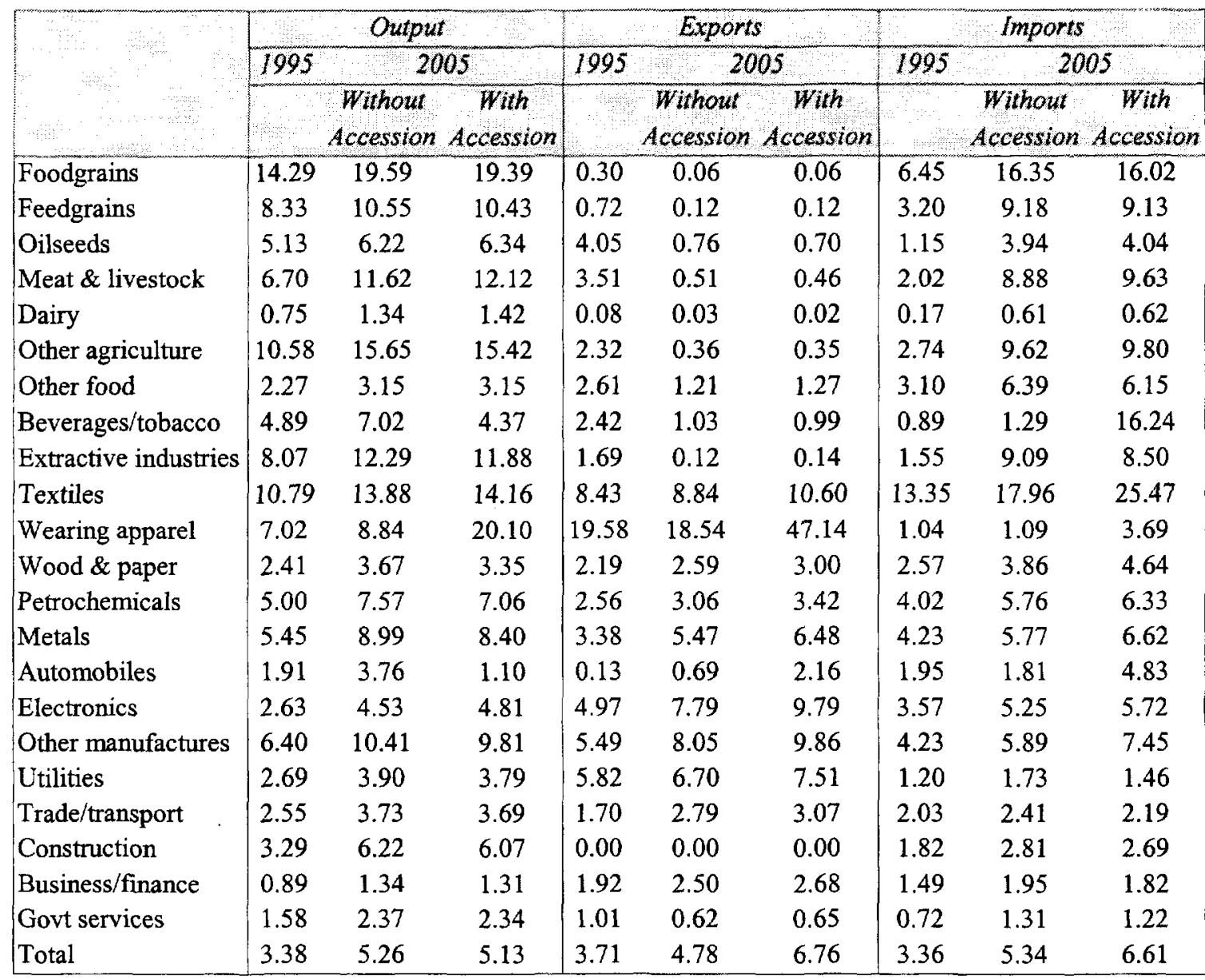

exports also increase dramatically, rising by 375 percent over the decade, compared to 45 percent in the case of no accession, for the same reason (columns 4 and 5, Table 8). As a result China's share of world export markets for apparel also increases substantially, to over 47 percent. The expansion of the apparel sector stimulates input demand for imported textiles, which increase by 272 percent by 2005 .

The automobile sector, and a number of high-tech sectors, experience very substantial increases in their exports under the accession scenario, as their costs are reduced following liberalization. Despite this increase in exports, the model results suggest that output of the automobile sector will fall, with the sharp reduction in the tariff 
on this sector. Table 4 shows that the average tariff on automobiles and parts falls from 129 percent in the baseline to only 13.8 percent after accession. ${ }^{10}$

Table 7. China's Output, Employment and Wages (percent change 1995 to 2005)

\begin{tabular}{|l|cc|}
\hline & \multicolumn{2}{|c|}{ Output } \\
\cline { 2 - 3 } & Without Accession & With Accession \\
\hline Foodgrains & 46.3 & 44.5 \\
Feedgrains & 28.9 & 26.9 \\
Oilseeds & 32.4 & 32.3 \\
Meat \& livestock & 75.0 & 81.3 \\
Dairy & 74.9 & 84.4 \\
Other agriculture & 53.2 & 50.0 \\
Other food & 50.5 & 51.8 \\
Beverages/tobacco & 80.7 & 13.8 \\
Extractive industries & 61.9 & 60.2 \\
Textiles & 71.6 & 88.0 \\
Wearing apparel & 57.0 & 263.5 \\
Wood \& paper & 103.6 & 93.9 \\
Petrochemicals & 105.8 & 98.6 \\
Metals & 135.7 & 126.2 \\
Automobiles & 189.6 & -3.8 \\
Electronics & 142.5 & 169.1 \\
Other manufactures & 131.7 & 125.5 \\
Utilities & 103.2 & 101.2 \\
Trade/transport & 110.9 & 114.4 \\
Construction & 147.9 & 149.0 \\
Business/finance & 104.6 & 105.1 \\
Govt services & 85.0 & 85.9 \\
Wages of Skilled Labor & 39.2 & 42.2 \\
Wages of Unskilled Labor & 83.0 & 87.1 \\
\hline
\end{tabular}

The output growth of the high-tech sector ("electronics") is export driven with the export share growing from 7.8 percent to almost 10 percent. The export shares of all manufacturing sectors grow under WTO accession due to a rapid increase in intraindustry trade. Table 6 shows an increase both in the export and import shares of all manufactured goods.

${ }^{10}$ This model underestimates the potential increases in the efficiency of China's automobile sector since it assumes constant returns to scale. With high protection and the presence of economies of scale, the automobile industry in China is currently grossly inefficient as manifested by an excessive entry of firms and models, and sub-optimal scale. China has been trying to deal with this issue for twenty years or more by controlling entry through restrictions on the import of assembly lines and related equipment. But, as in other countries, these controls have been ineffective. Reducing protection, however, will force increased economies of scale, and hence efficiency. This in turn implies that China might become a much bigger exporter than our results suggest. 
Wages of unskilled workers are expected to grow at twice the rate of growth in wages of skilled workers during 1995-2005 period. This is expected given the projections of 12 percent growth in China's unskilled labor compared to 43 percent growth in skilled labor over the same period (Ahuja and Filmer, 1995). At the aggregate level, membership in the WTO is expected to have a positive effect on wages. This is due to the expansion under accession of China's labor intensive apparel sector. Other big employers include agriculture, extractive industries, electronics, and construction. This increase in demand

Table 8. China's Trade by Commodity and Composition of Value Added (\% changes between 1995 and 2005)

\begin{tabular}{|l|c|c|cc|cc|}
\hline & \multicolumn{2}{|c|}{ Imports (cif weights) } & \multicolumn{2}{c|}{ Exports (fob weights) } & \multicolumn{2}{c|}{$\begin{array}{c}\text { Composition of Value } \\
\text { Added }\end{array}$} \\
\cline { 2 - 8 } & \multicolumn{2}{|c|}{} & \multicolumn{2}{c|}{ Without } & With & \multicolumn{2}{c|}{ Without } & With & Without & With \\
& Accession & Accession & Accession & Accession & Accession & Accession \\
\hline Foodgrains & 240.4 & 233.9 & -76.9 & -77.9 & -26.1 & -29.5 \\
Feedgrains & 263.5 & 260.5 & -81.7 & -82.8 & -34.9 & -38.1 \\
Oilseeds & 321.2 & 331.7 & -82.0 & -83.6 & -33.1 & -35.4 \\
Meat \& livestock & 451.7 & $\mathbf{5 0 7 . 3}$ & -85.5 & -86.8 & -11.6 & -11.5 \\
Dairy & 318.1 & 324.2 & -70.0 & -71.9 & -11.6 & -10.0 \\
Other agriculture & 352.1 & 363.6 & -84.8 & -85.4 & -22.6 & -26.8 \\
Other food & 154.1 & 144.7 & -48.8 & -46.2 & -24.0 & -25.9 \\
Beverages/tobacco & 148.4 & $\mathbf{6 7 1 8 . 5}$ & -25.4 & -14.9 & -8.7 & -44.5 \\
Extractive industries & 719.9 & 681.6 & -92.6 & -90.9 & -18.2 & -21.8 \\
Textiles & 86.8 & $\mathbf{2 7 1 . 9}$ & 44.5 & $\mathbf{1 0 6 . 8}$ & -13.3 & -8.3 \\
Wearing apparel & 57.9 & $\mathbf{8 1 8 . 1}$ & 45.3 & $\mathbf{3 7 4 . 8}$ & -20.6 & 77.4 \\
Wood \& paper & 105.0 & 184.3 & 63.0 & 96.8 & 2.9 & -5.4 \\
Petrochemicals & 96.3 & 140.7 & 64.8 & 90.6 & 4.0 & -3.1 \\
Metals & 88.0 & 138.9 & 134.2 & 190.1 & 19.1 & 10.4 \\
Automobiles & 24.7 & $\mathbf{5 5 0 . 7}$ & 647.8 & $\mathbf{2 5 2 2 . 6}$ & 46.3 & -53.0 \\
Electronics & 101.4 & $\mathbf{1 4 6 . 6}$ & 125.9 & $\mathbf{1 9 4 . 9}$ & 22.5 & 31.3 \\
Other manufactures & 95.2 & 186.6 & 113.5 & 175.6 & 17.1 & 10.1 \\
Utilities & 95.0 & 64.5 & 57.2 & 79.7 & 2.7 & -1.8 \\
Trade/transport & 63.4 & 46.7 & 113.0 & $\mathbf{1 3 3 . 5}$ & 6.6 & 4.6 \\
Construction & 101.2 & $\mathbf{9 2 . 7}$ & 5.6 & $\mathbf{2 0 . 2}$ & 25.3 & 21.5 \\
Business/finance & 75.2 & 63.3 & 82.4 & $\mathbf{9 8 . 5}$ & 3.4 & 0.1 \\
Govt services & 156.8 & $\mathbf{1 4 0 . 4}$ & -20.5 & -15.9 & -6.5 & -9.3 \\
\hline
\end{tabular}

for labor translates into a slight increase in wages due to accession (Table 7). It is likely that this slight strengthening of the market for labor would have favorable impacts on inequality and poverty, a result consistent with that of Wang and Fan (1998). 
On the import side, China becomes a much bigger market for its trading partners following accession to the WTO. Despite the fact that China's protection of the agricultural sectors is assumed to remain largely unchanged, China increases its agricultural imports of oilseeds, meat, and various food products. This increase in the importance of agricultural imports reflects the strong shift in comparative advantage away from agriculture implied by the baseline growth scenario as shown in the last two columns of Table 8. This structural change is an outcome of successful economic development, and is a sign of improved food security of the population in the sense of people's ability to acquire the food they need. It is associated with growth in agricultural production (Table 7) in addition to positive growth in agricultural imports and a decline in agricultural exports (Table 8).

With accession to the WTO, China is expected to continue being a powerful driver of growth, especially in East Asia. This can have significant implications for China's trading partners. For example, China's imports from ASEAN countries have grown over the past ten years by 389 percent, with their share in China's total imports growing from a little below 6 percent in 1990 to 9 percent in 1999. The ASEAN countries that have benefited the most from China's phenomenal growth in the nineties include Singapore, Thailand, Malaysia, and Indonesia (Figure 1). Would these countries continue to benefit from trade with China after its accession to the WTO or would China intensify trade with East Asia's industrialized and newly industrialized economies?

Our analysis helps to answer this question. Table 9 shows estimated changes in China's import volumes due to accession over the period 1995-2005, both by source and commodity. The numbers suggest that China's joining the WTO will provide the greatest 
Figure 1. China's Imports by Source (\$US Million)

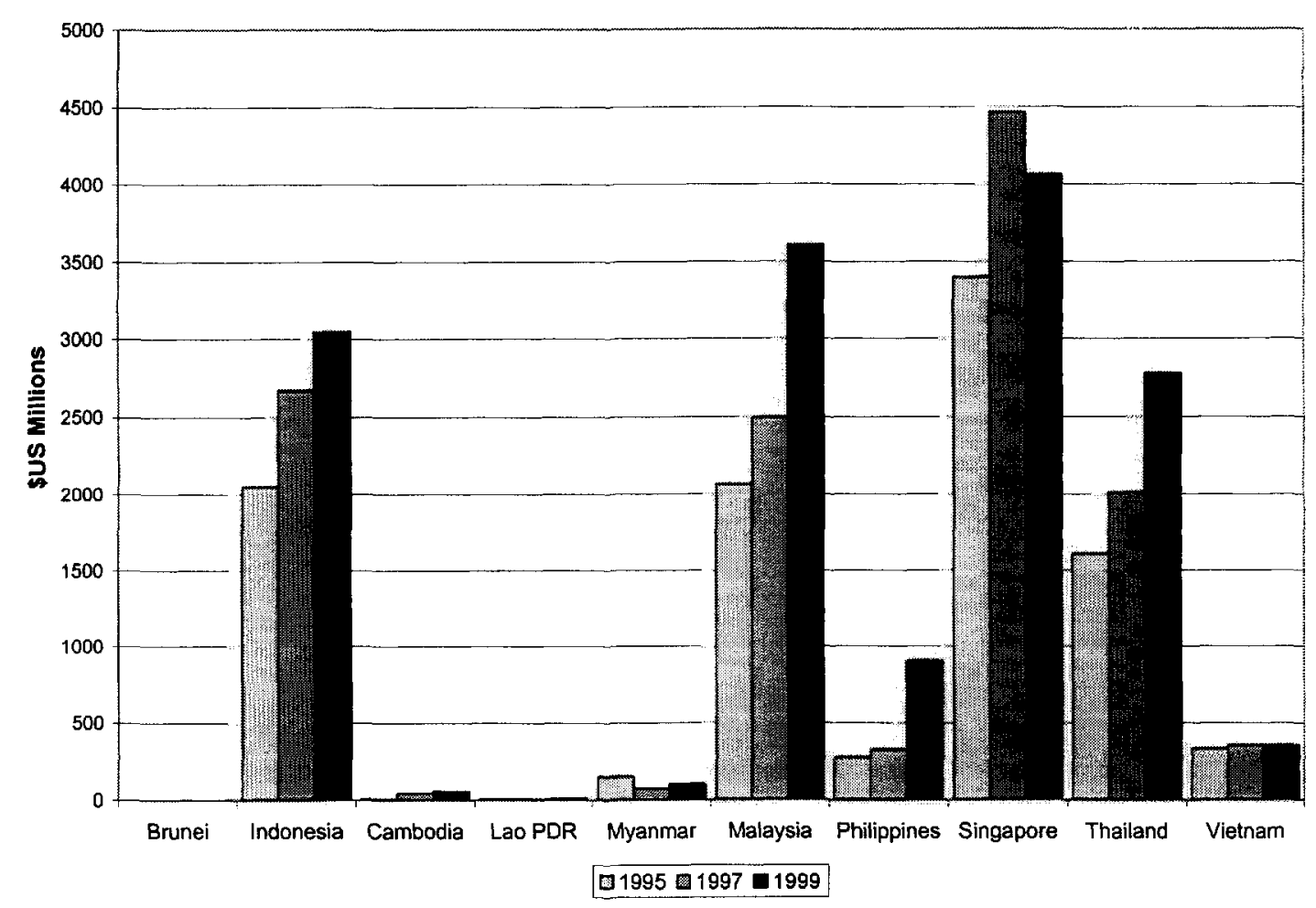

*Source: UN Comtrade System

mercantilist benefits to exporters in Taiwan (China), Japan, and other NICs in the region. Import volumes from these regions to China are estimated to increase by 83 percent, 47 percent, and 83 percent as a consequence of China joining the WTO. The imports with the largest volume increases are textiles and manufactures from Japan, Taiwan (China) and other NICs, petrochemicals from Taiwan (China) and other NICs, and apparel from other NICs. While intraregional trade in North East Asia will increase as a result of China's accession to the WTO, ASEAN countries might not benefit much. The estimated increases in China's import volumes from Indonesia and the other South East Asian countries are only around 3 percent and 14 percent, respectively. Most of the increases are in China's imports of textiles, wood products, and other manufactures from Indonesia 
and other South East Asia. The effect on other regions is modest. An interesting outcome is the positive and substantial increases in China's imports of manufactures from South Asia.

Table 9. Changes in China's import volumes due to accession, 1995-2005 (\$US Millions)

\begin{tabular}{|c|c|c|c|c|c|c|c|c|c|c|c|c|}
\hline 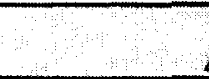 & $\begin{array}{l}\text { North } \\
\text { America }\end{array}$ & BU & Japan & $\begin{array}{l}\text { Trawhe, } \\
\text { Ohina }\end{array}$ & $\begin{array}{l}\text { Other } \\
\text { MCs }\end{array}$ & $\begin{array}{l}\text { Findo- } \\
\text { nesia }\end{array}$ & $\begin{array}{l}\text { Ower } \\
\text { SRA }\end{array}$ & South & $\begin{array}{l}\text { Lotin } \\
\text { Ameris: }\end{array}$ & MTNA & BIT & SSA \\
\hline Foodgrains & -72.6 & -19.6 & 0.0 & -7.4 & 0.0 & 0.0 & -34.3 & 3.1 & -1.2 & 0.0 & 0.0 & 0.0 \\
\hline Feedgrains & -28.1 & -1.4 & 0.0 & 0.0 & 0.0 & 0.0 & 0.0 & 0.0 & -0.6 & 0.0 & 0.0 & -0.2 \\
\hline Oilseeds & 10.9 & 0.2 & 0.0 & -0.1 & 0.0 & 0.0 & 0.0 & 0.6 & 2.5 & 0.0 & 0.9 & 0.0 \\
\hline $\begin{array}{l}\text { Livestock- } \\
\text { Meat industry }\end{array}$ & 176.8 & 77.9 & 16.9 & -6.6 & 6.4 & 25.3 & 61.8 & 2.5 & 18.3 & 5.1 & 128.7 & 2.5 \\
\hline Dairy industry & 1.8 & 4.3 & 0.0 & -0.6 & -0.7 & 0.0 & 0.2 & 0.0 & 0.0 & 0.0 & 0.2 & 0.0 \\
\hline $\begin{array}{l}\text { Other } \\
\text { Agriculture }\end{array}$ & 113.6 & 8.9 & 0.1 & -17.0 & -25.9 & 11.9 & 45.6 & 15.1 & 66.0 & 1.5 & 29.4 & 61.1 \\
\hline $\begin{array}{l}\text { Other food } \\
\text { Processing }\end{array}$ & -51.1 & -34.5 & -19.0 & -13.6 & -54.0 & -7.7 & -112.2 & 35.6 & -93.7 & -0.3 & -10.3 & -0.6 \\
\hline $\begin{array}{l}\text { Beverages \&- } \\
\text { tobacco }\end{array}$ & 5143.7 & 1440.0 & 237.9 & -0.4 & 5843.0 & -0.1 & 18.7 & 0.0 & 3.4 & 0.0 & 2.4 & 2.9 \\
\hline $\begin{array}{l}\text { Natural } \\
\text { resources }\end{array}$ & 63.9 & 714.2 & 471.8 & 259.0 & 2.3 & -927.0 & -210.5 & -134.7 & -42.5 & -1030.9 & 136.6 & -394.5 \\
\hline Textiles & -390.3 & 599.2 & 6500.9 & 13213.2 & $\begin{array}{c}11240 . \\
2\end{array}$ & 310.1 & 625.4 & -248.9 & -173.9 & -18.9 & -47.3 & -33.6 \\
\hline Apparel & 131.2 & 115.0 & 670.8 & 564.9 & 5960.1 & 3.1 & 24.3 & 161.4 & 9.5 & 11.2 & 9.0 & 5.6 \\
\hline $\begin{array}{l}\text { Wood-paper } \\
\text { Industry }\end{array}$ & -505.9 & 922.3 & 477.4 & 1583.8 & 1334.3 & 554.5 & 104.7 & 12.5 & -100.1 & 9.4 & -44.2 & 26.2 \\
\hline $\begin{array}{l}\text { Petrochemical } \\
\text { Industry }\end{array}$ & -904.9 & -189.1 & 665.0 & 10542.2 & 3032.8 & 11.2 & 153.9 & -2.4 & 21.9 & -274.9 & -1504.4 & 17.5 \\
\hline Metals & 551.2 & 303.8 & -173.7 & 4047.1 & 3510.8 & 30.8 & 61.4 & 6.2 & -172.3 & -10.7 & -775.2 & -12.3 \\
\hline $\begin{array}{l}\text { Motor } \\
\text { vehicles* }\end{array}$ & -350.4 & 22946.3 & -1208.1 & -43.9 & -265.8 & 0.0 & -11.3 & -10.7 & -128.7 & -10.3 & -165.4 & 159.3 \\
\hline Electronics & -836.0 & -1633.1 & 5688.5 & -233.4 & 2123.0 & 0.1 & 198.9 & 3.1 & 7.6 & 0.2 & -4.0 & 2.5 \\
\hline $\begin{array}{l}\text { Other } \\
\text { Manufactures }\end{array}$ & -1943.9 & -2631.8 & 13113.4 & 17478.2 & $\begin{array}{c}17838 . \\
2\end{array}$ & 272.2 & 1220.6 & 1817 & 99.6 & 83.0 & -74.0 & -12.4 \\
\hline Total & 1109.8 & 22622.6 & 26441.7 & 47365.6 & $\begin{array}{c}50544 . \\
6\end{array}$ & 284.5 & 2147.2 & 1661.1 & -484.5 & -1235.7 & -2317.6 & -176.0 \\
\hline Total (\%) & 2.4 & 40.0 & 47.1 & 83.0 & 83.2 & 3.0 & 13.7 & 45.5 & -4.0 & -7.6 & -18.5 & -2.9 \\
\hline
\end{tabular}


Table 10. Welfare Changes due to China's Accession to the WTO

\begin{tabular}{|c|c|c|c|c|}
\hline CountriesRegions & $\begin{array}{l}\text { Treome in } \\
\text { 1995 } \\
\text { Bilion USS }\end{array}$ & $\begin{array}{l}\text { Income Change } \\
\text { in Baseline wo } \\
\text { Wio, 1995-2005 } \\
\text { billion USS }\end{array}$ & $\begin{array}{l}\text { Treome Change } \\
\text { due to Who } \\
\text { Bilion USS }\end{array}$ & $\begin{array}{l}\text { Income Change } \\
\text { Due to WTO As } \\
\text { a share in base } \\
2005 \text { income } \\
(\%)\end{array}$ \\
\hline China & 714 & 577 & 28.6 & 2.2 \\
\hline Developed Countries & 22141 & 5240 & 19.7 & 0.1 \\
\hline North America & 7976 & 2561 & 9.5 & 0.1 \\
\hline Western Europe & 8650 & 1828 & 7.1 & 0.1 \\
\hline Japan & 5095 & 724 & 2.9 & 0.1 \\
\hline Australia \& New Zealand & 420 & 127 & 0.2 & 0 \\
\hline Developing Countries & 5465 & 1935 & 7.8 & 0.1 \\
\hline East Asia & 1448 & 582 & 12.5 & 0.6 \\
\hline Taiwan, China & 281 & 177 & 5.2 & 1.1 \\
\hline Other NIEs & 624 & 238 & 7.8 & 0.9 \\
\hline Indonesia & 200 & 50 & -0.2 & -0.1 \\
\hline Other Southeast Asia & 343 & 118 & -0.4 & -0.1 \\
\hline South Asia & 441 & 249 & -4.0 & -0.6 \\
\hline India & 331 & 188 & -3.2 & -0.6 \\
\hline Other South Asia & 109 & 61 & -0.8 & -0.5 \\
\hline Latin America & 1360 & 406 & 0.06 & 0 \\
\hline Brazil & 701 & 191 & 0.03 & 0 \\
\hline Other Latin America & 660 & 215 & 0.1 & 0 \\
\hline Middle East \& N. Africa & 848 & 278 & -0.4 & 0 \\
\hline Sub-Saharan Africa & 320 & 110 & 0.1 & 0 \\
\hline Eastern Europe and FSU & 792 & 179 & -0.2 & 0 \\
\hline Rest of the World & 256 & 132 & -0.3 & -0.1 \\
\hline Total & 28320 & 7752 & 56.1 & 0.2 \\
\hline
\end{tabular}

Table 10 shows regional income and welfare changes due to China's WTO accession both as a percentage of income growth over the 10 year period without WTO and as a share of income in the base year (1995). These results suggest that China will be the biggest beneficiary of accession to the WTO, followed by the industrialized economies and the newly industrialized countries in East Asia. The gains to China are understated because we do not take into account the welfare gains from reducing the variation of tariffs within our product aggregates in the manner suggested by Bach and 
Martin (2001). When Bach, Martin and Stevens (1996) adjusted for this in a partial equilibrium context, they found the gains to China almost doubled when appropriate aggregators were used. While the developing countries as a whole and the world as a whole also benefit from China becoming a more open economy as a member of the WTO, most developing countries competing with China in third markets will lose from China's accession to the WTO. The countries in South Asia are expected to be hurt the most, followed by Indonesia and some other Southeast Asian countries, mainly because of the removal of MFA restrictions on China's apparel exports. Losses to countries in the Middle East and North America, Eastern Europe and Former Soviet Union and others are negligible.

Comparisons of these results with those from other studies is complicated by the fact that most other studies have used proxies for the liberalization experiment, such as proportional cuts in protection. They can be directly compared with the results presented in Bach, Martin and Stevens (1996), who found gains to China of \$17 billion when tariff exemptions were (partially) allowed for, and global gains of $\$ 48$ billion. A recent study by Wang (2001), which uses the same tariff bindings in its estimates of liberalization finds an increase in China's real income of $\$ 188$ billion over the ten years 2000 to 2010, or $\$ 19$ billion per year, and an increase in world income of $\$ 89$ billion per year. The larger results for global trade reform in the Wang study reflect the inclusion of a link between industry productivity and the share of imported intermediate inputs used in each sector. While we believe that such linkages exist, and are potentially quite potent in developing economies, we have been unable to identify reliable estimates of the response 
parameters and have therefore chosen to present our estimates as representing a lower bound.

\section{CONCLUSIONS}

The trade reforms associated with China's accession to WTO are part of a long term movement to greater openness and integration into the world economy. Their full effects can only be understood if they are considered in the context of China's existing trade policies, and particularly the important duty exemptions provided for processing trade.

China has committed to make substantial reductions in the tariffs applied on manufactures - a set of reductions that we estimate will reduce the weighted average tariffs applied on these products from 24 percent in 1995 to 7 percent after the accession commitments are fully phased in. In agriculture, it is much more difficult to ascertain the extent of any liberalization because of our limited knowledge about current protection rates, and the complex nature of protection under the Tariff Rate Quota system for some major commodities. In contrast with some other studies, such as Fan and Li (2000), we conclude that little short-run liberalization of agriculture will be required, but we feel that much more work is needed before much confidence could be placed in this conclusion. In the longer run, however, we think it likely that accession will help China retain an efficient agricultural sector. Another important aspect of liberalization will be the phaseout of the MFA quotas that have hampered China's textile and clothing sector.

Our simulation analysis is conducted in the context of the rapid growth and structural change in the Chinese economy. We find that accession has a very strong impact on China's trade growth but, because we have not included an endogenous growth 
linkage between openness and growth, a much smaller impact on its shares of output. With accession, China's share of world exports rises from 3.7 percent in 1995 to over 6.8 percent. While accession has a large impact on China's export shares, its effect is smaller than found in other studies that do not incorporate the effects of duty exemption schemes in the base (e.g. Walmsley and Hertel, 2000). The duty exemptions represent partial liberalization, and the fact that this is in the base needs to be taken into account.

At the sectoral level, the most important impact of accession is on the apparel market, where China increases its share of world export markets to 47 percent. While enormous, this is much smaller than estimates obtained previously without taking the implications of tariff exemptions into account.

In our analysis, accession appears to have favorable impacts on the demand for both skilled and unskilled labor. This follows from the expansion of labor intensive sectors such as clothing, modest expansions in some labor-intensive agricultural sectors such as meat production. Due to further lowering of the trade distortions under the new offer, China's gains from joining the WTO will be magnified as a result of the improved efficiency of the Chinese economy and increased investment flow into the region. This analysis, however, ignores important dynamic considerations which might augment the estimated gains for China.

Our results provide some important findings about the likely response of the Chinese economy to accession but, at the same time, highlight a number of areas in which our ignorance is profound, and more research is needed if appropriate policy responses are to be adopted. One of these areas is clearly agricultural trade, where our lack of knowledge about the base level of agricultural protection creates uncertainty 
about whether accession will have a substantial liberalizing effect. Another is clearly the abolition of the textile quotas, whose impacts are likely to be enormous, but for which we rely on very dated estimates of protection. A third is the automobile sector, which will clearly undergo wrenching changes during its transition to becoming a much more efficient and export-oriented sector and whose features are not well captured by our model. It is also clear that the contingent protection measures included in the agreement will require careful analysis and policy responses if they are not to greatly hinder China's integration into the world economy. 


\section{References}

Anderson, K. , Francois, J. Hertel, T., Hoekman, B. and Martin, W. 2000. 'Potential Gains from Trade Reform in the New Millennium', Paper presented at the Third Annual Conference on Global Economic Analysis, June 27-30, Monash University, Australia.

Ahuja, and Filmer, D. 1995. 'Educational attainment in developing countries: new estimates and projections disaggregated by gender', Policy Research Working Paper 1489, World Bank.

Anderson, K. and Hayami, Y. 1986. The Political Economy of Agricultural Protection: East Asia in International Perspective, Allen and Unwin, Sydney.

Bach, C., Dimaranan, B., Hertel, T. and Martin, W. 2000. 'Market growth, structural change, and the gains from the Uruguay Round', Review of International Economics 8(2): 295-310.

Bach, C. and Martin, W. 2001. 'Would the right tariff aggregator for policy analysis please stand up?', Journal of Policy Modeling (forthcoming).

Bach, C., Martin, W. and Stevens, J. 1996. 'China and the WTO: tariff offers, exemptions and welfare implications', Weltwirtschaftliches Archiv 132(3):409-31.

Bernard, A. and Jones, C. 1996. 'Productivity Growth Across Industries and Countries: Time Series Theory and Evidence', Review of Economics and Statistics LXXVIII(1):135-46.

Bloom, D. and Williamson, J. G. 1998. 'Demographic transitions and economic miracles in emerging Asia', World Bank Economic Review, 12(3):419-56.

Carter, C. 2001. 'China's trade integration and impacts on factor markets', Mimeo, University of California, Davis.

Carter, C., Chen, J. and Rozelle, S. 1998. 'China's state trading in grains: an institutional overview', Processed, University of California at Davis.

Carter, C. and Huang, Jikun 1998. 'China's agricultural trade: patterns and prospects', Processed, University of California-Davis.

Chen, Xiwen 1999. 'The WTO and the Sino-US agricultural agreement', Symposium on WTO and the Chinese Economy sponsored by the State Information Center, Beijing, May 22-23.

Davey, W. 1998. 'Article XVII GATT: an Overview', in Cottier, T. and Mavroidis, P. eds. State Trading in the Twenty-First Century, Studies in International 
Economics, The World Trade Forum, Volume 1, University of Michigan Press, Ann Arbor.

Deardorff, A. 2001. 'International Provision of Trade Services, Trade, and Fragmentation', World Bank Policy Research Working Paper No. 2548, World Bank, Washington DC.

Development Research Centre 1998. The Global and Domestic Impact of China Joining the World Trade Organization, Development Research Centre of State Council, Beijing.

EU 2000. The Sino-EU agreement on China's accession to the WTO: results of the bilateral negotiations, http://europa.eu.int/comm/trade/bilateral/china/wto.htm.

Fan, Ming-tai and Zheng, Yu-xin 2000. 'China's trade liberalization for WTO accession and its effects on China - a computable general equilibrium analysis', Paper for presentation to the Third Annual Conference on Global Economic Analysis, Monash University, June 28-30.

Fan, Zhai and Li, Shantong 2000. 'The implications of accession to WTO on China's economy', Paper for presentation to the Third Annual Conference on Global Economic Analysis, Monash University, June 28-30.

Gilbert, J. and Wahl, T. 2001. 'Applied General Equilibrium Assessments of Trade Liberalization in China', Mimeo, Washington State University.

Findlay, C., Martin, W. and Watson, A. 1993. 'Policy Reform, Economic Growth and China's Agriculture', Development Centre Studies, OECD.

Francois, J. and Martin, W. 1995. 'Multilateral Trade Rules and the Expected Cost of Protection', Discussion Paper No. 1214, Centre for Economic Policy Research.

Gehlhar, M., Hertel, T. and Martin, W. 1994. 'Economic Growth and the changing structure of trade and production in the Pacific Rim', American Journal of Agricultural Economics 76(December):1101-1110.

Hathaway, D. and Ingco, M. 1996. 'Agricultural liberalization and the Uruguay Round', in Martin, W. and Winters, L. A. eds. The Uruguay Round and the Developing Countries, Cambridge University Press, Cambridge.

Ianchovichina, E., Martin, W., and Fukase, E. 2000. 'Modeling the Impact of China's Accession to the WTO', $3^{\text {rd }}$ Annual Conference on Global Economic Analysis, Monash University, Australia, June 27-30, 2000. www.monash.edu.au/policy/ conf/cnprog1.htm. 
Ianchovichina, E., Martin, W. and Wood, C. 2000. 'Effects of the Vietnam-US bilateral trade agreement', Mimeo, World Bank.

Kueh, Y. 1987. 'Economic Decentralization and Foreign Trade Expansion in China' in Chai, J. and Leung C.K. eds. China's Economic Reforms. Hong Kong: University of Hong Kong.

Lardy, N. 1991. Foreign Trade and Economic Reform in China, 1978-1990. Cambridge: Cambridge University Press.

Martin, W. 1993. 'Modeling the Post-reform Chinese Economy.' Journal of Policy Modeling, 15(5 and 6):545-79.

Martin, W. 2001a. 'Trade policy reform in the East Asian transition economies', World Bank Policy Research Working Paper No. 2535, World Bank, Washington DC.

Martin, W. 2001b. 'Implications of reform and WTO accession for China's agricultural trade policies', Economics of Transition (forthcoming).

Martin, W. and Mitra, D. 2001. 'Productivity growth and convergence in agriculture versus manufacturing' Economic Development and Cultural Change 49(2):40322, January.

Martin, W., Dimaranan, B., Hertel T. and Ianchovichina, E. 2000. 'Trade Policy, Structural Change and China's Trade Growth', Working Paper No. 64, Stanford Institute for Economic Policy Research, Stanford University.

Nehru, V. and Dhareshwar, A. 1993. 'A new database on physical capital stock: sources, methodology and results' Revista de Análisís Económico 8(1):37-59, June.

Ravallion, M. and Chen, S. 2001. On the incidence of China's growth in the 1990s, Mimeo, World Bank.

Rozelle, S., Park, A., Huang, Jikun and Hehui, Jin 1996. 'Bureaucrat to Entrepreneur: the Changing Role of the State in China's Transitional Commodity Economy' Stanford University: Mimeo.

USITC 1999. Assessment of the Economic Effects on the United States of China's Accession to the WTO, Publication 3229, US International Trade Commission, Washington DC.

USTR 1999. Statement of Ambassador Charlene Barshevsky regarding broad market access gains resulting from China WTO negotiations, US Trade Representative, Washington DC, April 8. 
Walmsley, T. and Hertel, T. 2000 'China's Accession to the WTO: Timing is Everything', paper presented at the Third Annual Conference on Global Economic Modeling, Melbourne, Australia.

Wang, Zhi and Fan, Zhai 1998. 'Tariff reduction, tax replacement, and implications for income distribution in China', Journal of Comparative Economics 26:358-87.

Wang, Zhi 2001. The impact of China's WTO accession on patterns of world trade, Paper prepared for the International Agricultural Trade Research Consortium, May 18$20,2001$.

World Bank 1994. China: Foreign Trade Reform. Washington DC: World Bank.

World Bank 1997a. China: Long-term Food Security. Washington DC: World Bank.

World Bank 1997b. China Engaged: Integration with the World Economy. Washington D.C.: World Bank.

World Bank 1999. World Development Indicators. World Bank, Washington DC.

World Trade Organization 1994a. The Results of the Uruguay Round of Multilateral Trade Negotiations. Geneva: World Trade Organization.

World Trade Organization 1994b. Uruguay Round of Multilateral Trade Negotiations: Legal Instruments Embodying the Results of the Uruguay Round of Multilateral Trade Negotiations, Vol 4, Geneva: World Trade Organization. 



\section{Policy Research Working Paper Series}

Title

WPS2602 Sugar Policy and Reform

WPS2603 How the Quality of Institutions Affects Technological Deepening in Developing Countries

WPS2604 Eliminating Excessive Tariffs on Exports of Least Developed Countries

WPS2605 The Macroeconomic Impact of Bank Bank Capital Requirements in Emerging Economies: Past Evidence to Assess the Future

WPS2606 Exchange Rate Risk Management: Evidence from East Asia

WPS2607 The Economical Control of
Infectious Disease

WPS2611 Trade and Production Fragmentation: Central European Economies in European Union Networks of Production and Marketing

WPS2612 Contractual Savings, Capital Markets, and Firms' Financing Choices

WPS2613 Foreign Direct Investment and Poverty Reduction

WPS2614 South-South Regional Integration and Industrial Growth: The Case of the Andean Pact
Author

Donald F. Larson

Brent Borrell

George R. G. Clarke

Bernard Hoekman

Francis $\mathrm{Ng}$

Marcelo Olarreaga

Maria Concetta Chiuri Giovanni Ferri

Giovanni Majnoni

George Allayannis

Gregory W. Brown

Leora F. Klapper

Mark Gersovitz

Jeffrey S. Hammer

Thorsten Beck

Thorsten Beck

Masahiro Kawai

Richard Newfarmer

Sergio Schmukler

Bartlojiej Kaminski

Francis $\mathrm{Ng}$

Gregorio Impavido

Alberto R. Musalem

Thierry Tressle

Michael Klein

Carl Aaron

Bita Hadjimichael

Dorsati H. Madani
May 2001

\section{Date}

May 2001

May 2001

May 2001

May 2001

May 2001

May 2001

May 2001

June 2001

June 2001

June 2001

June 200

June 2001
P. Braxton 32720

\section{Contact for paper}

P. Kokila 33716

P. Sintim-Aboagye 38526

L. Tabada 36896

E. Mekhova 85984

A. Yaptenco 31823

H. Sladovich 37698

A. Yaptenco 38526

A. Yaptenco 38526

E. Khine 37471

L. Tabada 36896

Z. Fanai 33605

R. Simms 37156 


\section{Policy Research Working Paper Series}

Title

WPS2615 Trade, Growth, and Poverty
WPS2616 Reforming Land and Real Estate
Markets
WPS2617 Shanghai Rising in a Globalizing
World
WPS2618 Globalization and the Challenge
for Developing Countries

WPS2620 Who Owns the Media?

WPS2621 Does Indonesia Have a "Low-Pay" Civil Service?

WPS2622 Community Programs and Women's Participation: The Chinese Experience Xinyi Dai
Aart Kraay

Ahmed Galal

Omar Razzaz

Shahid Yusuf

Weiping Wu

Shahid Yusuf

Michele Cavallo

Giovanni Majnoni

Simeon Djankov Caralee McLiesh

Tatiana Nenova

Andrei Shleifer

Deon Filmer

David L. Lindauer

David Coady

Limin Wang
Date

June 2001

\section{Contact}

for paper

\section{E. Khine} 37471

June 2001

D. Dietrich 34995

June 2001

S. Yusuf 82339

June 2001

S. Yusuf 82339

June 2001

E. Mekhova 85986

June 2001

R. Sugui 37951

June 2001

H. Sladovich 37698

June 2001

L. Wang

37596 